\title{
Studies on morbidity pattern in Pantja goat under range conditions in Tarai region of Uttarakhand
}

\section{BS Khadda, Brijesh Singh, DV Singh, JL Singh, RK Sharma \& SB Bhardwaj}

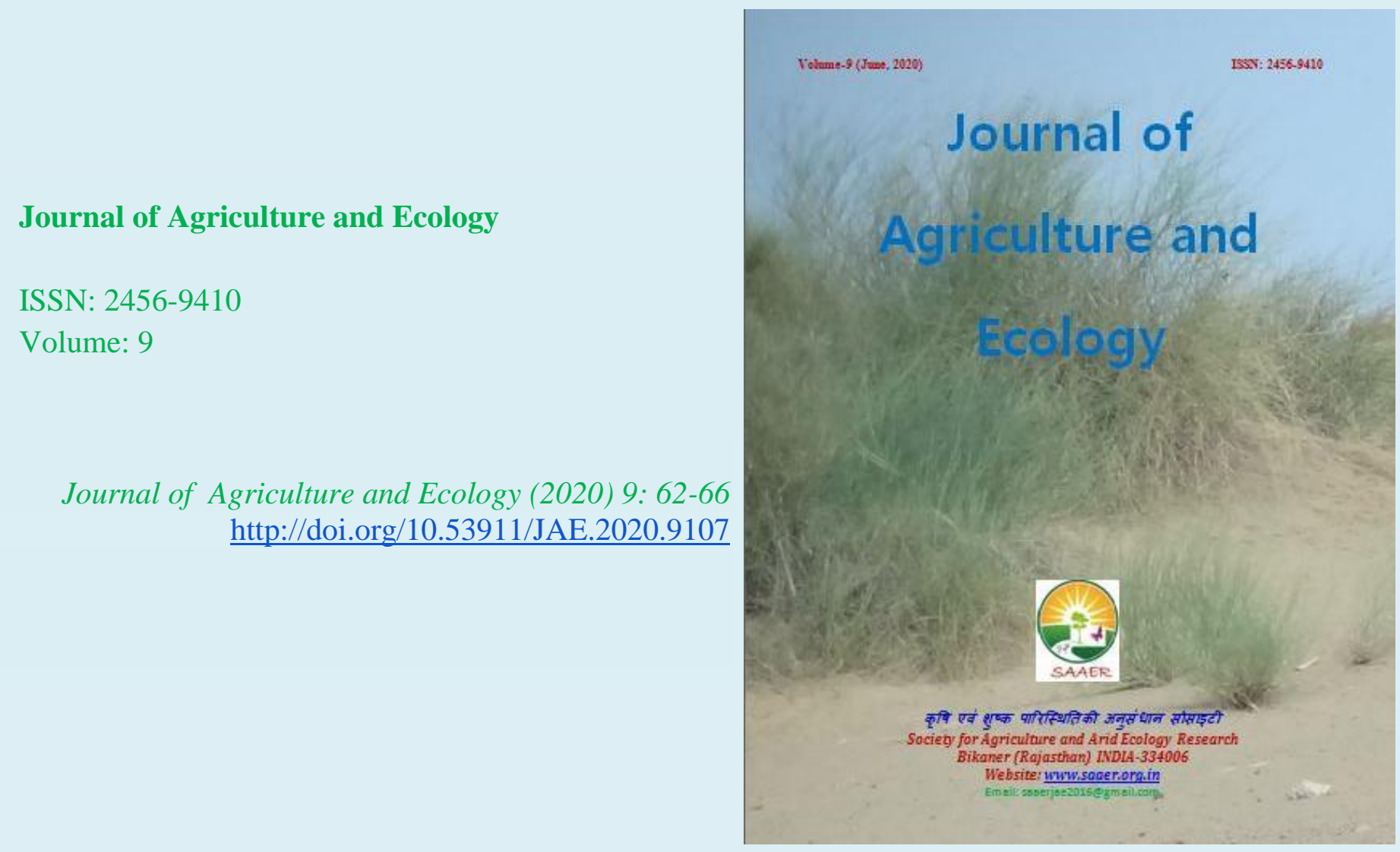




\title{
Studies on morbidity pattern in Pantja goat under range conditions in Tarai region of Uttarakhand
}

\author{
BS Khadda ${ }^{1} \not$, Brijesh Singh, DV Singh, JL Singh, RK Sharma \& SB Bhardwaj \\ Department of Livestock Production Management \\ College of Veterinary and Animal Science \\ G. B. Pant University of Agriculture and Technology, Pantnagar-263145 \\ ${ }^{l}$ SMS (AH), ICAR-CIAH KVK, Panchmahal \\ Corresponding author: BS Khadda, khadda74@gmail.com
}

\section{Article Info}

Article history

Received: 10 May 2020

Accepted: 15 June 2020

Available online: 30 June 2020
Abstract

A study was conducted to collect the base line information on various factors affecting morbidity pattern in goats with special reference to Pantja breed under village conditions of Udham Singh Nagar and Nainital districts of Tarai region of the Uttarakhand during a period of two years (April, 2015 to March, 2017) under All India Co-ordinated Research Project on Goats (Pantja field Unit), Department of livestock Production and Management, College of Veterinary and Animal Sciences, G. B. Pant University of Agriculture and Technology, Pantnagar. The results of present study revealed that the overall morbidity among (9023 goats) surveyed population was 27.96 per cent. The results also indicated that Coccidiosis $(29.69 \%)$, infectious-enteritis (16.43\%), miscellaneous (16.47\%), pneumonia $(13.58 \%)$, toxaemia/ acidosis (10.53\%), general weakness (7.88\%), predation $(3.60 \%)$ and putrefied $(1.82 \%)$ were the common causes of morbidity. Among the total morbidity of goat flock faced heavy morbidity was found to be in kids (69.24\%) followed by young age (13.66\%) and adult $(17.10 \%)$. The Chi-square analysis of overall morbidity rate in goats with respect to district showed that the district had significant $(\mathrm{p}<0.01)$ effect on morbidity rates in goats.

Copyright $@ 2020$ Khadda et al., This is an open access article published under the terms of the Creative Commons Attribution License, which permits unrestricted use, distribution, and reproduction in any medium, provided the original work is properly cited.

Preferred citation: Khadda BS, Singh B, Singh DV, Singh JL, Sharma RK \& Bhardwaj SB. 2020. Studies on morbidity pattern in Pantja goat under range conditions in Tarai region of Uttarakhand. Journal of Agriculture and Ecology, 9: 62-66; http://doi.org/10.53911/JAE.2020.9107.

\section{Introduction}

The bestowal of agriculture sector to the total GDP in $1950-51$ was 50.50 per cent of which the share of animal husbandry was 15.50 per cent; from $1980-81$ to $2017-2018$ period the contribution of agriculture sector fell from 34.72 to 10.00 per cent, while the contribution of animal husbandry as per cent of agriculture went up from 13.88 in 1980-81 to 27.40 per cent in $2017-18$ (BAHS, 2019). The contribution of livestock sector to the total Indian GDP at current prices was 4.90 per cent. India's exports earning from livestock sector rose from Rs. 691.22 crores in 
1987-88 to Rs. 30866.51 crores in 2011-12, which speaks about potential of animal husbandry sector to boost national economy (BAH\&FS, 2015). Goat production from centuries has been an integral component of farming system and a primary source of livelihood for resource it poor villagers. Resource poor people on Zero input mostly rear goats in India. Goats are the backbone of rural economy of the arid, semi-arid and hilly regions of our country and regarded as "ATM" means any time money and any time milk. The domestic goat Capra hircus is one of the oldest domesticated farm animal and has been associated with man from up to 9000 to 7000 B.C. (Banerjee 2005). Goat is basically an animal of Asian origin which is distributed all over the world and inhabits almost all agro-climatic regions from arcticcircle to the equator. It is a very important source of livelihood of the people below the poverty line. They give rapid return on account of their short kidding intervals, higher rate of prolificacy and marketing of related products can be done at any time easily. India possess 34 recognized breeds of goats, which constitute 20-25 per cent of the total goat population and remaining are non- descript with mixed features (Khadda et al., 2019). The success of goat farming depends on the health of the flock. Good health of the animals not only increases the productivity but also the profitability ((Khadda et al., 2018). The effect of diseases on livestock productivity includes; reduced feed intake, change in digestion and metabolism, increased morbidity and mortality decreased rates of reproduction, weight gain and milk production. Morbidity significantly affects the economic returns from goat production. Understanding of morbidity pattern in different age groups and seasons will be of immense help in health management of livestock to reduce mortality. Keeping in view, a study was conducted to document the existing factors affecting morbidity pattern in goats under village conditions in Tarai region of Uttarakhand and to formulate suitable intervention policies.

\section{Material and Methods}

A bench mark survey was conducted to collect the base line information on various factors affecting morbidity pattern in goats with special reference to Pantja breed under village conditions of Udham Singh Nagar and Nainital districts of Tarai region of the Uttarakhand during a period of two years (April, 2015 to March, 2017) under All India Co-ordinated Research Project on Goats (Pantja field Unit), Department of livestock Production and Management, College of Veterinary and Animal Sciences, G. B. Pant University of Agriculture and Technology, Pantnagar. Multistage sampling method was adopted for the selection of respondents. Four clusters (Bhimtal, Tilpuri, Bara and Kunda) were selected from two districts (Udham Singh Nagar and Nainital). A total of one hundred thirteen villages were surveyed on the basis of availability of Pantja goats. An individual farmer rearing Pantja goats formed the unit of a sample. A list of goat rearing families of the selected villages was prepared with the help of village Pradhan and Patvari and mostly all Pantja goat rearers were selected for survey from each village. Thus, 645 selected respondents (reared 9023 goats) were interviewed and the desired information was collected. The data were collected by 
personal interview techniques through an interview schedule by administering a developed questionnaire and also by direct observation in the farmer's flocks. Before administering interview schedule to the sample subjects, specific objectives and the purpose of the survey was explicitly explained. The questions in the schedule were presented to them in their own dialect ensuring that they perceive the questions correctly. The response to each question in the schedule was coded and tabulated respondent wise in a master sheet. The qualitative data were quantified accordingly and tabulated to draw meaningful inferences. Therefore, appropriate table was prepared, keeping in view the specific objectives of the study. The collected data were subjected to basic statistical analysis as per Snedecor \& Cochran (1994). Chi Square ( $\chi 2)$ was used to observe the effect districts on different factors affecting morbidity pattern in goats.

\section{Results and Discussion}

The results regarding various cause of morbidity in goats under field condition are presented in Table 1. The results of present study revealed that the overall morbidity among (9023 goat) surveyed population was 27.96 per cent. The results also indicated that coccidiosis (29.69\%), infectious-enteritis (16.43\%), miscellaneous (16.47\%), pneumonia (13.58\%), toxaemia/ acidosis $(10.53 \%)$, general weakness $(7.88 \%)$, predation $(3.60 \%)$ and putrefied $(1.82 \%)$ were the common causes of morbidity. The findings were in agreement with that reported by Khan (1997), Mishra (1989), Singh, (2016) and Khadda et al. (2017). Sawargaonkar et al.
(1996) reported that the highest mortality in kids due to pneumonia.

The Chi-square analysis $\left(\chi^{2}=\right.$ $\left.25.47^{* *}\right)$ of overall morbidity rate in goats with respect to district showed that district had significant $(p<0.01)$ effect on morbidity rates in goats. The district wise means morbidity among the surveyed (1272/4384) population were 29.02 per cent in U.S.Nagar district and corresponding values (1254/4639) were 27.03 per cent in Nainital district. The similar findings were also reported by Singh, (2016) and Khadda et al. (2017). Among the total morbidity of goat flock faced heavy morbidity $69.24 \%$ in kids (0-3 months of age) and the main cause of mortality were coccidiosis $(42.02 \%)$ followed by infectious-enteritis (19.55\%), miscellaneous (11.21\%), pneumonia $(9.43 \%)$, toxaemia/ acidosis $(6.91 \%)$, general weakness $(6.23 \%)$, predation $(2.97 \%)$ and putrified $(1.65 \%)$. The overall population morbidity in young age were found 13.66 per cent and the main causes of morbidity were miscellaneous $(22.90 \%)$ followed by pneumonia $(18.84 \%)$, toxaemia/ acidosis (16.23\%), general weakness (15.94\%), infectious-enteritis (14.20\%), predation $(6.67 \%)$, coccidiosis $(2.61 \%)$ and putrefied $(2.61 \%)$.

In case of adult morbidity was recorded 17.10 per cent and the main cause of morbidity were miscellaneous (32.64\%) followed by pneumonia $(26.16 \%)$, toxaemia/ acidosis $(20.60 \%)$, general weakness $(8.10 \%)$, infectious-enteritis $(5.56 \%)$, predation $(3.70 \%)$, putrefied $(1.85 \%)$ and coccidiosis $(1.39 \%)$. The Chi-square analysis $(\chi 2$ $\left.=647.73^{* *}\right)$ of overall morbidity rate in goats with respect to age showed that age of animals had significant $(\mathrm{p}<0.01)$ effect on morbidity rates in goats. Present findings were in agreement with those reported by Sharma et al. (2007), Singh et al. (2009), Kumar (2011), Singh et al. (2014) and Singh (2016) and Khadda et al. (2017). 
Journal of Agriculture and Ecology, 2020, Vol. 9, 62-66

http://saaer.org.in

Table 1. Causes of morbidity in Pantja goat under range conditions

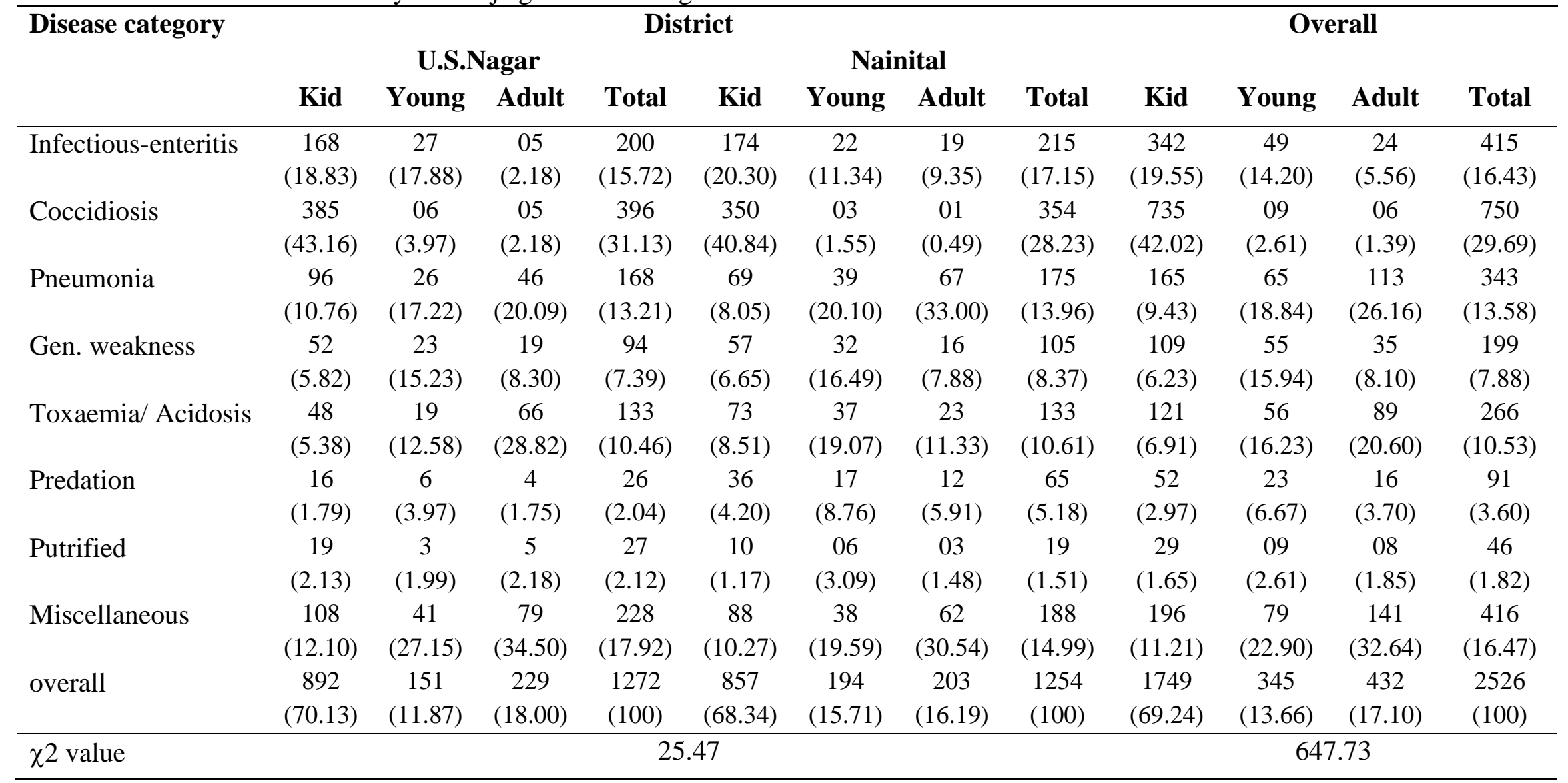




\section{Conclusion}

Based on results of present study it was concluded that the Coccidiosis, infectiousenteritis and pneumonia are major causes of morbidity, so improved hygiene and good managemental practices should be taken to reduce the occurrence of diseases. Morbidity was significantly associated with age groups, suggesting that more care and attention need to be paid in kids of $0-3$ months age irrespective of district. Regular vaccination and deworming of the flock and treatment of the affected animals can reduce the losses in goat rearing.

\section{Reference}

BAH\&FS. 2015. Basic Animal Husbandry and Fisheries Statistics. 2015. Ministry of Agriculture, Department of Animal Husbandry, Dairying and Fisheries, Krishi Bhawan, New Delhi.

BAHS, 2019. Basic Animal Husbandry Statistics. 2019. Ministry of Fisheries Animal Husbandry and Dairying, Department of Animal Husbandry and Dairying, Krishi Bhawan, New Delhi.

Banerjee GC. 2005. Text book of animal husbandry $8^{\text {th }}$ edition, Oxford and IBH publishing Co. Ltd, New Delhi.

Khadda BS, Brijesh Singh, Singh DV, Singh JL, Singh CB \& Singh SK. 2017. Causes of morbidity in Pantja goats under field conditions in their native tract. Paper presented in International Conference on Global Research initiatives for Sustainable Agriculture \&Allied Science (GRISAAS-2017) held on 02-04 Dec., 2017 at RCA, MPUA\&T, Udaipur (Rajasthan).

Khadda BS, Brijesh Singh, Singh DV, Singh SK, Singh CB, Singh JL \& Singh CB. 2018. Survey on health management practices followed by Pantja goat keepers in Tarai region of Uttarakhand. Indian Journal of Animal Production, 34 (3-4): 63-66.

Khadda BS, Singh B, Singh DV, Singh SK, Singh CB, Singh JL \& Palod J. 2019. Growth performance of Pantja goats under field conditions in their home tract. Indian Journal Animal Research 53 (2): 264-69.Khan, B.U. 1997. Project Co-ordinators Report, AICRP on goats, CIRG, Makhdoom, Mathura, India.

Mishra RK. 1989. Project co-ordinators report, AICRP on goats, ICAR-CIRG, Makhdoom, Mathura, India.

Sawargaonkar SP, Degloorkar NM, Moregaonkar SB, Kulkarni GD \& Khan MA. 1996. Studies on mortality pattern in caprine in Marathwada (Maharastra). Indian Veterinary Journal 73: 212-213.

Sharma SK, Nagda RK, Kumar U \& Khadda BS. 2007. Mortality pattern in Sirohi goats under field conditions.

Singh MK, Rai B, Kumar A, Simaria MB \& Singh NP. 2009. Performance of Zalawadi goats under range conditions. Indian Journal of Animal Sciences, 79 (1): 68-72.

Singh MK, Rai B, Dixit AK, Singh R \& Singh SK. 2014. Management practices of goats in Bundelkhand region. The Indian Journal of Small Ruminants, 20 (2): 99-105

Singh B. 2016. Annual report (2015-16), All India coordinated research project on goat improvement (Pantja field unit), G. B. Pant University of agriculture and Technology, Pantnagar (Uttarakhand)

Snedecor GW \& Cochran WB. 1994. Statistical methods. $8^{\text {th }}$ Edn. The Iowa State University Press, Ames, IOWA, USA. 